\title{
AR Antagonist BMS-641988
}

National Cancer Institute

\section{Source}

National Cancer Institute. AR Antagonist BMS-641988. NCI Thesaurus. Code C62522.

An androgen receptor (AR) antag onist with potential antineoplastic and anti-androgenic activities. BMS-641988 binds to the androgen receptor in target tissues, thereby preventing androgen-induced receptor activation, and facilitates the formation of inactive complexes that cannot be translocated to the nucleus. This may inhibit androgen-dependent gene expression, subsequently leading to an inhibition of cell growth and apoptosis in AR-expressing cells. 